Article

\title{
Assessing Livelihood Resilience of Artisanal Fisherfolk to the Decline in Small-Scale Fisheries in Ghana
}

\author{
Iddrisu Amadu 1,2,3,*(D), Frederick Ato Armah 4 (D) and Denis Worlanyo Aheto 1,3 \\ 1 Centre for Coastal Management-Africa Centre of Excellence in Coastal Resilience, University of Cape Coast, \\ Cape Coast PMB TF0494, Ghana; daheto@ucc.edu.gh \\ 2 Emperiks Research Limited, Tamale NT0085, Ghana \\ 3 Department of Fisheries and Aquatic Sciences, University of Cape Coast, Cape Coast PMB TF0494, Ghana \\ 4 Department of Environmental Science, University of Cape Coast, Cape Coast PMB TF0494, Ghana; \\ farmah@ucc.edu.gh \\ * Correspondence: iddrisu.amadu@stu.ucc.edu.gh
}

Citation: Amadu, I.; Armah, F.A.; Aheto, D.W. Assessing Livelihood Resilience of Artisanal Fisherfolk to the Decline in Small-Scale Fisheries in Ghana. Sustainability 2021, 13, 10404. https://doi.org/10.3390/su131810404

Academic Editor: Just

Tomàs Bayle-Sempere

Received: 23 July 2021

Accepted: 13 September 2021

Published: 18 September 2021

Publisher's Note: MDPI stays neutral with regard to jurisdictional claims in published maps and institutional affiliations.

Copyright: (c) 2021 by the authors. Licensee MDPI, Basel, Switzerland. This article is an open access article distributed under the terms and conditions of the Creative Commons Attribution (CC BY) license (https:// creativecommons.org/licenses/by/ $4.0 /)$.
Abstract: The concept of livelihood resilience provides a unique framework for understanding challenges in complex social-ecological systems (SESs) and fostering sustainability. Despite the crises many small-scale fisheries (SSFs) are facing, few studies have operationalized the concept in the context of declining SSFs in developing countries. This study aims to assess the resilience of artisanal fisherfolk livelihoods and its predicting factors in three fishing communities-Elmina, Jamestown, and Axim-in Ghana. A total of 1180 semi-structured interviews were conducted with fishers, fish processors, and mongers. Descriptive and multivariate statistical techniques were used to analyze the data. The results show that the livelihood resilience of fisherfolk increases with an increased level of education and varies by gender. Male fisherfolk with secondary/post-secondary level education had the highest proportion (50\%) of more resilient livelihoods. Only $36 \%$ of female fisherfolk with secondary/post-secondary level education had more resilient livelihoods. While $40 \%$ of male fisherfolk with no formal education had less resilient livelihoods, the livelihoods of half $(51 \%)$ of females fisherfolk with no formal education were less resilient. The sociodemographic characteristics including wealth status, dependency ratio, marital status, religion, and ethnicity; contextual factors (community); and other relevant factors (experience in fishing, membership of fisherfolk association/group, and beneficiary of livelihood interventions) were found as predictors of the resilience of fisherfolks livelihoods. The findings suggest that interventions towards improving the livelihood resilience of fisherfolk need to consider individual- and household-level characteristics, as well as contextual factors such as marital status, religious affiliation, ethnicity, wealth status, dependency ratio, community, etc.

Keywords: social-ecological systems; sustainability; multiple stressors; vulnerability; coastal communities

\section{Introduction}

Small-scale fisheries around the world are experiencing crises [1]. This has been attributed to some pervasive multiple stressors occasioned by climate and human activities. The rising spate of adverse climate change impacts, illegal, unreported, and unregulated (IUU) fishing, overfishing, and pollution is a toxic cocktail that threatens many fish stocks [2-7]. In Ghana, these pressures are exacerbated by the evolution of a very destructive form of IUU practice popularly known as "saiko" [8]. The practice is an illicit trade involving the targeting, catching, and transhipment of staple catch of canoe fishers by industrial trawlers to some accomplice artisanal canoe fishers for onward sale $[9,10]$. This, together with other illegal activities that pillage the nation's small pelagic fish stocks known as the "people's fish," is emboldened by the nearly open access and weak governance regime [11]. According to the EJF (2019), the practice costs more than 50 million 
dollars, pushing the nation's pelagic fish stocks to the brink of collapse [12]. Meanwhile, the Fisheries Amendment Act 2002 (ACT 625) bans all forms of IUU activities including saiko in the nation's waters [13]. Another milestone is the Fisheries Management Plan (2014-2019) that sets out specific policies to revive the collapsing fishery [14]. However, these activities perpetuate as a result of a lack of transparency and other weaknesses in law enforcement and compliance. Recently, the government of Ghana implemented the close season policy for the second time after gross resistance by fisherfolks (fishers, fishmongers, and fish processors) across many small-scale fishing communities on its introduction in 2019 [13]. This was aimed at reducing the pressure on the fish stocks and allow for rejuvenation. The measures instituted remain woefully inadequate in addressing the myriad of active stressors that could plunge SSF into serious social-ecological systems (SESs) crises. This is evidenced by the continuous decline in artisanal fish landings recorded since 1990 [15]. Crises in complex SESs, such as the small-scale fisheries of Ghana (Figure 1), which involves the interactions between the resource system (marine fish stock), resource units (small-pelagic fish stocks), resource users (fisherfolk), and governance system (formal and informal institutions such as the Ministry of Fisheries and Aquaculture Development, Fisheries commission, and Chief fishermen), as Ostrom (2009) suggested, would result in outcomes that impinge on the livelihoods and well-being, as a well as functioning, of the resource [16].

The livelihoods and well-being of the over 2.7 million artisanal fisherfolk are increasingly exposed to shocks from the declines owing to the dependence of small-scale fishing communities on these resources [17]. Adapting to these shocks amidst heightening socioeconomic deprivations, increasing population, poverty, limited livelihood opportunities, and relatively low literacy levels in coastal communities remains a serious challenge [18-20]. Studies suggest that aside from the management and governance context, individual characteristics of fisherfolk ranging in age, years in fishing, educational attainment, membership of fisherfolk social networks, and access to livelihood options are important determinants of their capacity to adapt to long-term change [21]. Some notable strategies fisherfolk commonly adopt in response to shocks from decreasing fish catch include, but are not limited to, the diversification of their source of income, change fishing methods and tools, migration, and sale of physical assets [22-25]. In Ghana, fisherfolk mobilize adaptive capacity against these shocks through the use of novel fishing techniques and technologies, support from networks, family, and friends, corrupt practices, etc. [26]. Nevertheless, some of the strategies fisherfolk employ in mobilizing adaptive capacity such as the use of chemicals in fishing are rather "maladaptive", as they tend to exacerbate pressures on fish stocks. In complex and dynamic SESs such as small-scale fisheries, livelihood adaptation strategies are mainly "reactive" and not "anticipatory", therefore losing sight of long-term change and sustainability.

Kalikoski et al. (2010) suggest that the ability of fisherfolk to anticipate, cope, and recover from shocks has an inverse relationship with the vulnerability of their livelihood [27]. Under this context, the concept of livelihood resilience emerges as one of the most important frameworks that capture (ex-ante and ex-post) the capacities of livelihoods to maintain or enhance their functions in the face of shocks. Some researchers opine that applying the concept of livelihood resilience is the best way to promoting and fostering sustainability in livelihoods in SESs facing uncertain futures [28,29]. Currently, small-scale fisheries are among the most dynamic and uncertain SESs around the world [30]. This concept is particularly desired as efforts at building resilience invariably nips vulnerability to the bud and develops the capacity to bounce back to its original structure and function in face of potential shocks. According to Tanner et al. (2015), livelihood resilience is the capacity of individuals (actors) of various generations to maintain or enhance their livelihood opportunities and general well-being in the face of social, economic, political, and environmental shocks [31]. Understanding the livelihood resilience of artisanal fishers in small-scale fisheries facing crises from multiple climate and human-induced stressors could contribute immensely to policies/interventions aiming at fostering long-term trans- 
formation and sustainability in the sector. Ifejika Speranza et al. (2014) indicate that the concept of livelihood resilience offers a useful framework that could serve as a monitoring and evaluation tool for livelihood resilience-building interventions/policies [32]. However, empirical studies assessing the resilience of fisherfolk in Ghana are scarce.

Measuring livelihood resilience presents one of the most difficult tasks to researchers and practitioners. Quandt et al. (2017) attribute this to the lack of standard protocol for the selection of indicators for measuring livelihood resilience [33]. Nevertheless, recent studies have proposed conceptual and analytical frameworks to guide the determination of suitable indicators for livelihood resilience in specific contexts. Some of these include an indicatorbased framework for livelihood resilience in SESs proposed by Ifejika Speranza et al. (2014); frameworks for post-disaster scenarios [34]; and the framework for agroforestry livelihoods proposed by Quandt et al. (2017). Even though specific frameworks for livelihood resilience in small-scale fisheries facing declines are absent in the literature, the broad and flexible indicators under the framework developed by Ifejika Speranza et al. (2014) have greater prospects for operationalization. The aim of this study is to apply the framework as a conceptual lens to empirically measure and determine the relevant factors that systematically influence the livelihood resilience of artisanal fishers in Ghana's SSF.

\section{Operationalizing the Indicator-Based Livelihood Resilience Framework}

Based on an extensive review of theoretical and empirical studies on livelihood resilience, Ifejika Speranza et al. (2014) proposed one of the broadest frameworks for analyses of livelihood resilience in SESs under crises from climate change and other stressors. Unlike previous conceptualizations, Ifejika Speranza et al. (2014) indicate that in SESs, three pillars - the capacity of social actors to learn, self-organize, and buffer the effects of shocks on their livelihood-together build livelihood resilience of actors. This has also been highlighted as an important framework for analyzing livelihood resilience in SESs [35,36]

Buffer capacity has different meanings in different contexts. Here, buffer capacity is a measure of the extent to which the livelihoods of fisherfolk can absorb shocks without losing their ability to function and maintain their structure and identity [37]. Buffer capacity is constructed from fisherfolk's access or ownership of a combination of tangible and intangible assets commonly referred to as "livelihood capitals" [38]. These include physical capital such as canoes/boats, and fishing gear; financial capital, e.g., loans and savings; social capital including relations such as family, and friends; political capital, for instance, closeness, access, and complaints to the political authority about grievances; cultural capital such as innovations from indigenous knowledge and skills; natural capital such as access to productive fishing grounds [39,40]. Notably, Speranza (2013) opined that buffer capacity entails access or ownership of livelihood capitals, as well as the capability to maintain or increase these capitals [41]. Livelihood capital plays a crucial role in the kind of livelihood strategies that can be adopted in the face of shock [42]. These capitals or assets are not merely resources but assets that give one the capability to construct a livelihood [43].

The capacity for self-organization is another important pillar of livelihood resilience that concerns the institutions (formal and informal), cooperations, and networks, and the extent to which actors rely on their resources [32]. The activities of actors in a socialecological system are controlled by local institutions such as norms and values, as well as formal regulations that emerge from a dialectic of social structures in the system [44]. In most small-scale fishing communities in Ghana, notable institutions such as the office of the "chief fisherman" and "queen fishmonger" govern the activities of fisherfolk and address issues about their welfare [26,45-47]. They enforce rules/traditional regulations and strengthen norms that relate to the activities of fisherfolk at the fish landing sites and markets. Additionally, at the centre of self-organization is the micro-level interactions between actors in social networks that create norms and group rules $[48,49]$. The contribution of social networks in resilience-building has gained prominence in the literature over the years [50]. In most small-scale fishing communities in Ghana, fisherfolk have 
local networks such as associations, groups, and cooperatives [45]. However, membership without active participation in the activities of these social networks may not foster trust-a form of social capital that is fundamental to the processes through which self-organization leads to resilience in the face of shocks [32,51].

Social actors learn from interactions in SESs. Cognizant of the numerous definitions of learning, here, we define learning as the process that occurs when knowledge or skills are acquired and directly or indirectly applied in the real world [52]. Learning forms the foundation for adaptive management in SESs where the previous experience of shocks informs current actions of agents in the system. De Kraker (2017) suggests that promoting social learning is one of the important ways of enhancing resilience in SES [53]. According to Ifejika Speranza et al. (2014), the social and organizational theories of learning offer important pointers to the capacity of an actor to learn in SESs. Bandura's (1969) social learning theory explains how newly acquired experience, i.e., knowledge of skills through interactions among social actors shapes behaviour [54-56]. Some relevant antecedents of the capacity to learn that contribute to livelihood resilience include understanding of the nature of the threats on livelihood, commitment to learning, collective vision, and ability to identify, share, or transfer knowledge [57-59].

\section{Materials and Methods}

\subsection{Study Area}

This study was carried out in three small-scale fishing communities in the eastern, central and western coast of Ghana including Jamestown, Elmina, and Axim, respectively (Figure 2). Jamestown is located at the heart of the Asheidu Keteke Sub-Metropolitan in the Greater Accra Region. It is one of the indigenous coastal communities in Accra, noted for its dense population [60,61]. Axim is the capital of the Nzema East Municipality in the Western Region. According to the Ghana Statistical Service (2014), Axim has a population of about 20,655 [62]. It is composed of three settlements-lower and upper Axim, and the Apewosika community. Elmina is located in the Komenda-Edina-Eguafo-Abrem (KEEA) District of the Central Region, while Jamestown is in the Asheidu Keteke Sub-Metropolitan in the Greater Accra Region. Jamestown is dominated by the Ga ethnic group, while the majority of those in Elmina and Axim are Fantes and Nzemas, respectively [47]. It is one of the most densely populated small-scale fishing communities in the KEEA District of the Central Region. The community has a population of about 32,819 [63].

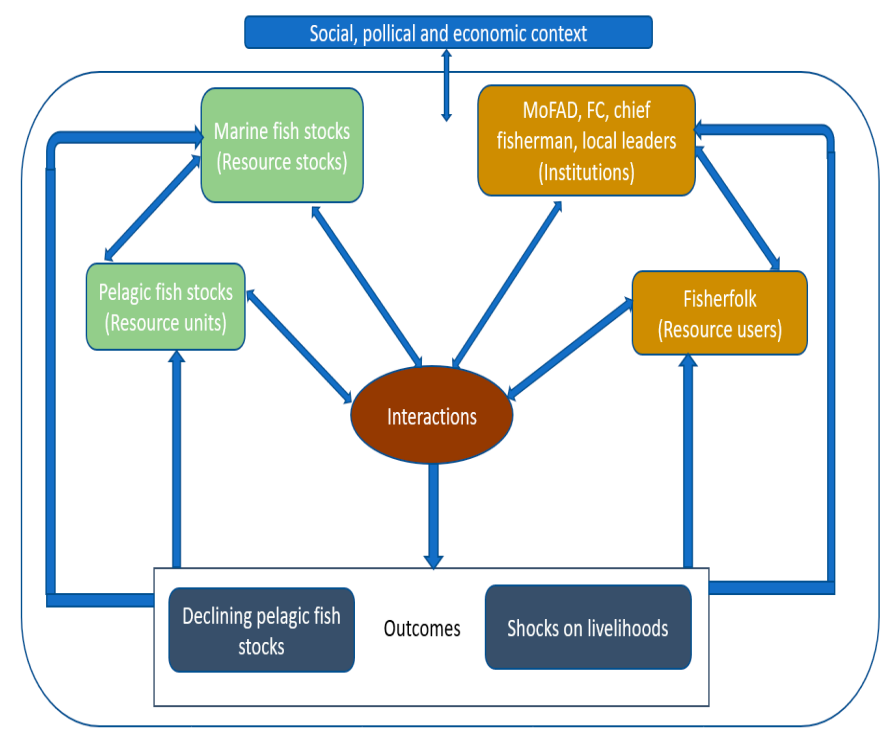

Figure 1. Social-ecological system framework in the context of Ghana's small-scale fisheries (Adapted from Ostrom, 2009). 
Small-scale fishing activities such as fishing, fish mongering, and fish processing are the mainstay of people in these communities. However, these livelihoods are constructed from vulnerability contexts commonly characterized by limited livelihood opportunities/alternate livelihood options, low levels of education, and relatively high socioeconomic deprivations in Ghana [18-20,60,61]. Such a level of vulnerability exposes the livelihoods of fisherfolk in these communities and makes them increasingly sensitive to shocks from various climate and non-climate stressors that threaten fish stocks. Understanding the resilience of their livelihoods and the factors associated with it under this context could serve as a baseline and contribute immensely to programming interventions aimed at improving fisherfolk's livelihood conditions and sustainability. This serves as an important basis for studying the resilience of fisherfolk's livelihoods in the three fishing communities.

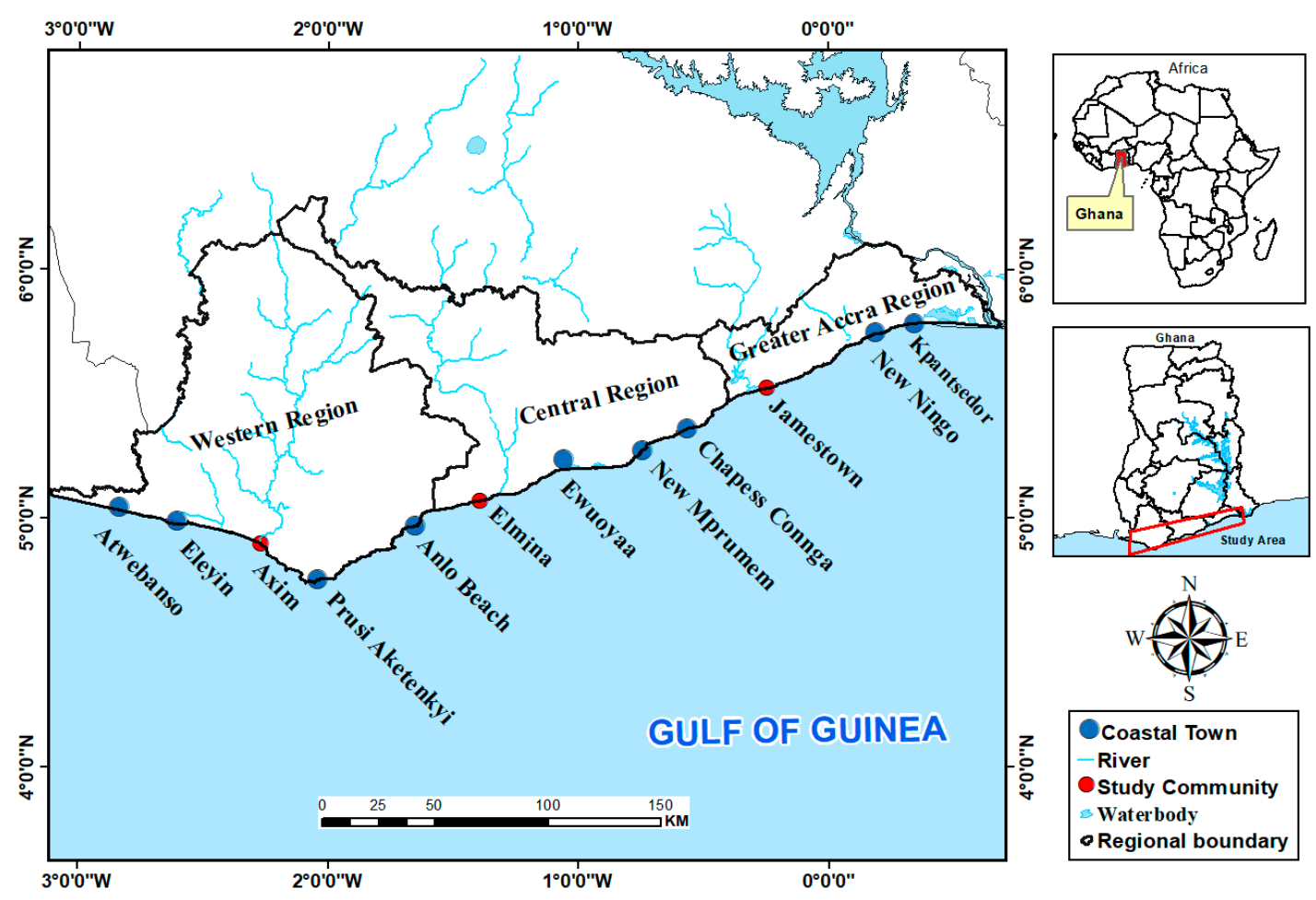

Figure 2. Map showing the three fishing communities.

\subsection{Research Design}

This study used a quantitative cross-sectional approach to examine the factors associated with the resilience of fisherfolk's livelihoods in the face of declining fisheries. The data were gathered between March and May 2021 in the three small-scale fishing communities (Elmina, Axim, and Jamestown). A semi-structured questionnaire was used for data collection. Field assistants were trained on the administration of the questionnaire, ethical standards, and COVID-19 safety protocols. Study respondents included fisherfolk (fishermen, fishmongers, and fish processors). Surveys were conducted in English and local languages, including Fante, Ga, and Nzema. A total of 1180 respondents were randomly sampled and interviewed. Each interview lasted between 30 to $45 \mathrm{~min}$.

\subsection{Research Instrument}

The questionnaire used is made up of four (4) sections. The first part of the questionnaire (Section A) consisted of an introductory statement and relevant sociodemographic characteristics of respondents. Some of the variables included age, gender, marital status, religious affiliation, the number of household members ( $<14$ years; $15-64$ years and $>65$ years), and household's access to basic services (drinking water, toilet facility, and cooking fuel), as well as access to refrigerator, television, radio and motorcycle/car. A 
"wealth status" index was then constructed from respondent's household access to durable assets (refrigerator, television, radio, and motorcycle/car) using principal component analysis (PCA). The wealth index was then categorized into three wealth quantiles (rich, middle, and poor) following [64]. A dependency ratio (DPR) status was also constructed by dividing the number of household members aged 15-64 years by the sum of those below 15 years and those above 64 years. This was then grouped into three DPR status quantiles "high", "moderate", and "low". The dependency ratio is one of the critical indicators of buffer capacity [32]. For instance, fisherfolk from a household with high dependency ratios invariably bear a relatively high financial burden, which could limit their capacity to make savings for security against livelihood shocks. The succeeding three (3) sections captured Likert scale questions (scale of 1 to 10) on the three pillars of livelihood resilience according to Ifejika Speranza et al. (2014): (i) buffer capacity; (ii) capacity for learning; (iii) capacity for self-organization. A total of 20 questions were developed through an extensive review of the literature [26,32,65-68]. They consisted of eight measurement items for buffer capacity and four each for capacity for self-organization and learning. For buffer capacity, measurement items centred around fisherfolk's ownership or entitlement to relevant livelihood capitals/assets (physical, financial, political, social, natural, and human). Capacity for self-organization was measured with variables on how institutions (norms and formal rules), and membership of social networks (fisher associations/cooperatives and groups) contribute to the resilience of their livelihoods. The knowledge of fisherfolk relative to the shock (declining fish catch) on their livelihood, experimentation, experience gained, and knowledge sharing were elicited by measures of learning capacity.

\subsection{Ethical Considerations}

The research protocols used in this study were reviewed and approved by the University of Cape Coast Institutional Review Board (UCCIRB). The clearance Identification (ID) number is UCCIRB/CANS/2020/06.

\subsection{Measurements}

\subsubsection{Measuring Livelihood Resilience}

Factor analyses (FAs) were conducted on the 20 measurement items considered for the 3 pillars of livelihood resilience. The internal consistency reliability of the measurement items was first ascertained using Cronbach's alpha $(\alpha=0.98)$. According to studies, a Cronbach's alpha greater than 0.70 is an indication of good internal consistency reliability of the measures. The suitability of the data for FA was then assessed using the KaiserMeyer-Olkin (KMO) at $\geq 0.8$ and Bartlett's tests of sphericity at $p \leq 0.05$. The two tests $(\mathrm{KMO}=0.906 ; p=0.000)$ showed that the data were suitable for factor analysis. Factor analyses were performed using the maximum likelihood technique and Promax rotation. Three factors with Eigenvalues greater than 1 were retained. Observed variables were retained based on the following criteria: (i) variable loading $\geq 0.5$, and (ii) communality of $\geq 0.60$. Based on this, the first factor (factor 1) consisting of eight variables measuring buffer capacity, the second factor (factor 2) with four variables measuring capacity for selforganization, and factor 3 with four variables on the capacity for learning were retained. To be sure that observed variables measured factors they were loaded under, internal consistency reliability was tested for each factor. Observed variables measuring buffer capacity showed an $\alpha=0.911$; capacity for self-organization $\alpha=0.892$; capacity for learning at $\alpha=0.905$. This implied that all variables measured the constructs they were developed to measure. Indices were then generated for the three pillars of livelihood resilience using regression weights. Using PCA, a livelihood resilience (LR) index was then generated from the three regression weights. The LR index scores ranged from 0 to 10 . For parsimony, as well as theoretical and practical relevance, the outcome variable "livelihood resilience" was then derived from the LR index by categorizing it into "less resilient (0-3.9), "resilient" (4.0-6.9), and "more resilient" (7.0-10.0). 


\subsubsection{Independent Variables}

The relationships between biosocial, sociocultural, contextual, and other relevant factors and the livelihood resilience of fisherfolk are examined. Biosocial factors considered in this study are gender (male, female) and age (young adults or those below 35 years; middle-aged adults for those 35-55 years; old-aged adults for those above 55 years) of respondents. The educational attainment (no formal, primary, secondary and tertiary), religious affiliation (Christianity, Islam, Traditional, and other), ethnicity (Fante, Ga, Nzema, and Ewe), marital status (never married, married, divorced/separated, widowed), wealth status (poor, middle, and rich), the dependency ratio (high, moderate, and low) and experience in fishing (years in fishing) (1-15, 16-30, 31-45, and 46-60 years) were the relevant sociocultural variables included. In terms of context, the community (Axim, Elmina, and Jamestown) of the residence of fisherfolk was considered. Other relevant factors including whether fisherfolk's only source of income is fishing/fish work (yes, no); previously benefitted from a livelihood empowerment intervention (yes, no); and membership of fisher/fish worker association (yes, no).

\subsection{Data Analyses}

The data were analyzed using Stata SE 14.0 (StataCorp, Texas TX, USA) and the Statistical Package for the Social Sciences (SPSS) software. To understand the distributions of all relevant variables, descriptive statistics (frequencies and percentages) were performed. Summaries of the results are presented in tables (Table 1) and Figure 3. To enhance visualization and appreciation of the study context, the data were integrated into a geographic information system (GIS) environment, and the livelihood resilience of fisherfolks across the study communities was presented using a map (Figure 4). The chi-square test of independence was then used to assess the associations between the livelihood resilience of fisherfolk and each of the independent variables. The strength of these associations was ascertained using the Cramer's V statistic. The results are presented in a contingency table (Table 2). An ordered logistic regression was then fitted to the data to observe the effects of the independent variables on the resilience of fisherfolk's livelihood. The results are presented in Figure 5 using odds ratios (ORs) at $p<0.05$ (see also Table S1).

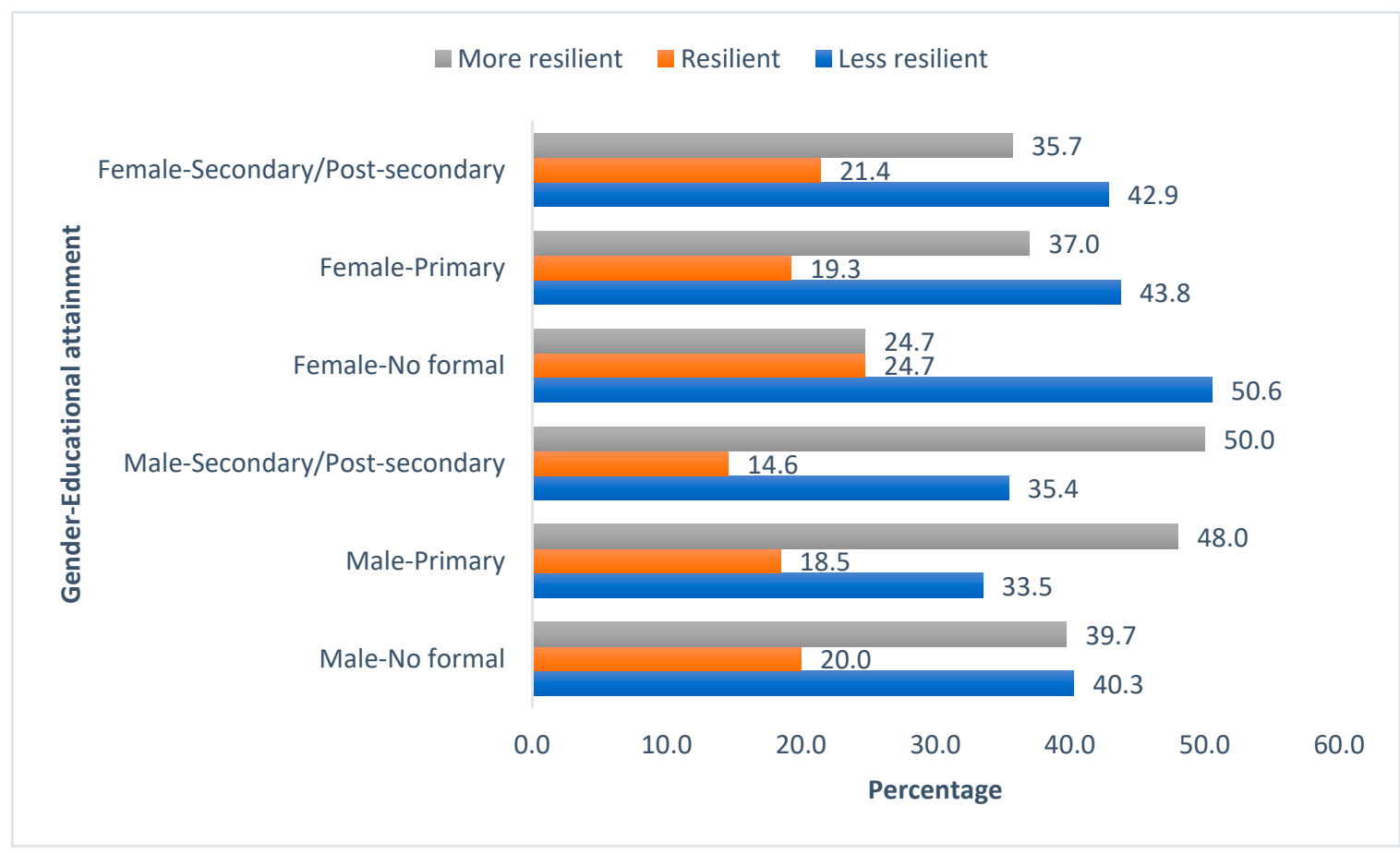

Figure 3. Livelihood resilience of fisherfolk by gender and education. 


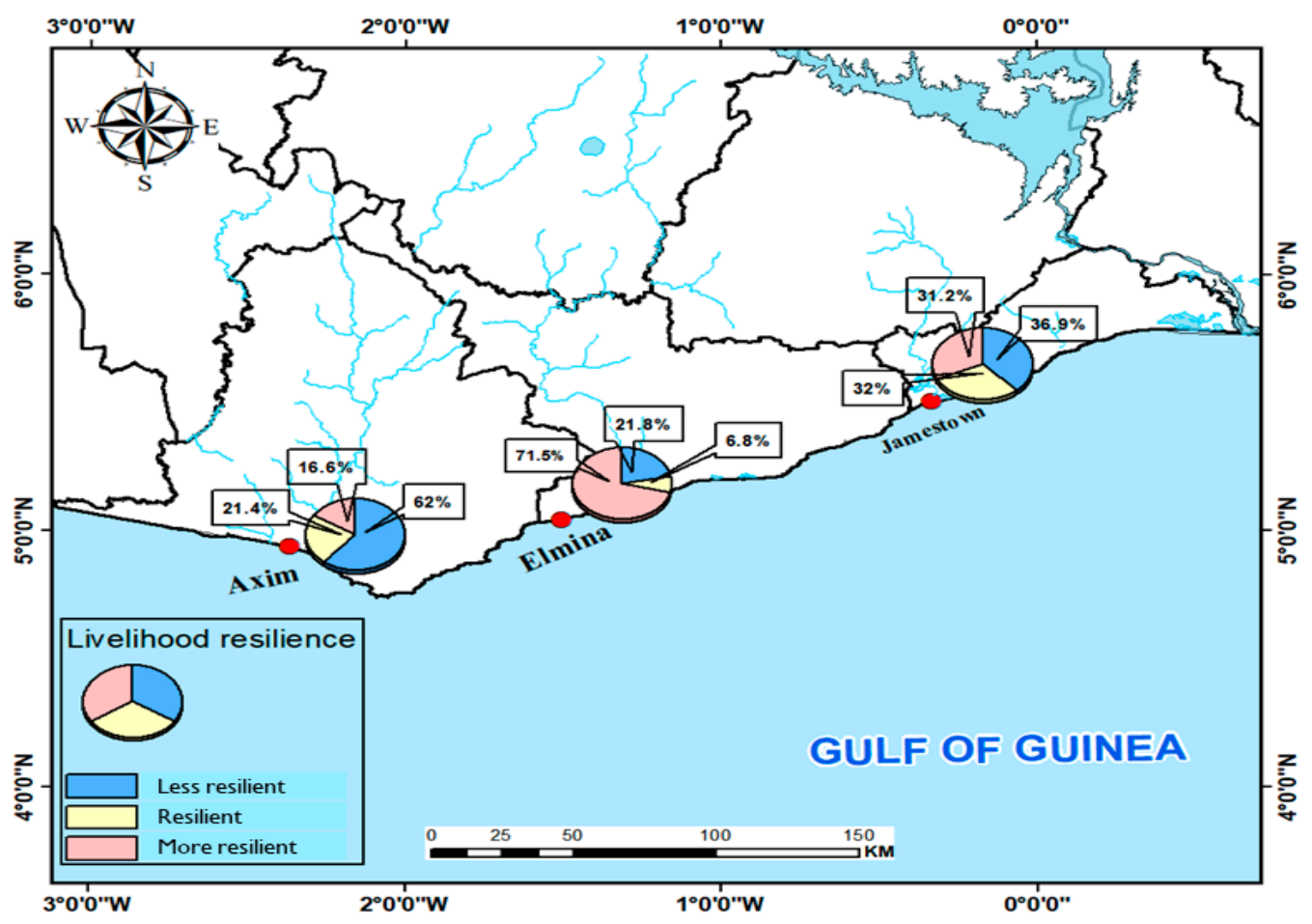

Figure 4. Map showing the distribution of livelihood resilience across study communities.

\section{Results}

\subsection{Sociodemographic Characteristics and Livelihood Resilience}

A total of 1180 fisherfolk were included in this study. Livelihood resilience increased with the increasing level of educational attainment of fisherfolk. Gendered differences in livelihood resilience were also observed. As shown in Figure 3, male fisherfolk with secondary/post-secondary level education had the highest proportion $(50 \%)$ of more resilient livelihood. Only 36\% of female fisherfolk with secondary/post-secondary level education had more resilient livelihoods. While $40 \%$ of male fisherfolk with no formal education had less resilient livelihoods, the livelihoods of half (51\%) of females fisherfolk with no formal education were less resilient. More than half (58\%) of the respondents were middle-aged adults, while young adults made up $29 \%$ of the respondents (Table 1 ). The old-aged adults were the least (13\%) age category among the respondents. Middleaged respondents had the highest (43\%) proportion among those whose livelihoods were more resilient, while old-aged adults were the highest $(46 \%)$ in the less resilient livelihood category.

In terms of religious affiliation, a majority of the respondents belonged to the Christian faith. Those who identify as traditionalists had the highest percentage $(60 \%)$ in the more resilient livelihood category, while those affiliated with other religions had the highest percentage $(61 \%)$ in the less resilient livelihood category. The respondents were dominated by married individuals (69\%), followed by those who never married (18\%). Similarly, married individuals represented the highest percentage (45\%) among respondents whose livelihoods were more resilient. In the less resilient livelihood category, divorced/separated respondents were the most (54\%). With regard to wealth status, only $2 \%$ of the respondents were rich. Respondents who were poor accounted for $46 \%$, while a little above (52\%) were made up of the middle category. The livelihoods of more than half $(62 \%)$ of the rich were more resilient. The poor dominated (49\%) among those with less resilient livelihoods.

Most of the respondents were from households with high dependency ratios, while $29 \%$ and $27 \%$ of respondents belonged to households with low and moderate dependency ratios, respectively. Those with a low dependency ratio were the highest (45\%) among the more resilient livelihood category. In the less resilient livelihood category, respondents with 
a moderate dependency ratio had the highest percentage (46\%), followed by those with a high dependency ratio (43\%). Most of the respondents (84\%) depend on fishing/fish work as their only source of income. Those who do not depend on fishing/fish work only as a source of income had the highest percentage (44\%) among the most resilient livelihoods category. Respondents with fishing/fish work as their only source of income were the highest (40\%) among the less resilient livelihood category.

A majority (42\%) of the respondents had 1-15 and 16-30 years of experience in fishing. Those with 1-15 years of experience in fishing had the highest percentage (48\%) among the respondents with more resilient livelihoods. More than half (61\%) of the respondents indicated that they are not members of fisher/fish worker associations at the moment. However, those who were members of fisher/fish worker associations had the highest percentage (68\%) among the more resilient livelihood category. Respondents who have not previously benefitted from a livelihood intervention for fisherfolk were the majority $(82 \%)$ of the sample. However, $76 \%$ of respondents who benefitted from a livelihood intervention for fisherfolk had a more resilient livelihood, compared to $32 \%$ for those who did not benefit from any livelihood intervention. In terms of ethnicity, Fante (53\%) and Ga (39\%) groups dominated the sample. Even though Ewes and those in other ethnic groups each constituted only $1 \%$ of the total respondent, Ewes had the highest percentage (75\%) among the respondents in the more resilient livelihood category. Finally, respondents from the three communities of Elmina (34\%), Axim (33\%), and Jamestown (33\%) were nearly equal. In terms of livelihood resilience, however, respondents from Elmina had the highest percentage $(72 \%)$ of more resilient livelihood. The less resilient livelihood category was dominated (62\%) by respondents from Axim (see Figure 4).

Table 1. Sociodemographic characteristics of respondents.

\begin{tabular}{|c|c|c|c|c|c|}
\hline Variable & $n$ & $\%$ & Variable & $n$ & $\%$ \\
\hline Sex & & & Is fishing/fish work your only source of income? & & \\
\hline Male & 792 & 67 & No & 185 & 16 \\
\hline Female & 388 & 33 & Yes & 995 & 84 \\
\hline Age & & & Experience (Years in fishing) & & \\
\hline Young-adults & 339 & 29 & $1-15$ & 496 & 42 \\
\hline Middle-aged & 690 & 58 & $16-30$ & 490 & 42 \\
\hline Old adults & 151 & 13 & $31-45$ & 181 & 15 \\
\hline Educational attainment & & & $46-60$ & 13 & 1 \\
\hline No formal & 547 & 46 & Membership of fisherfolk association/group? & & \\
\hline Primary & 571 & 48 & No & 720 & 61 \\
\hline Secondary/Post-secondary & 62 & 5 & Yes & 460 & 39 \\
\hline Religious affiliation & & & $\begin{array}{c}\text { Previously benefitted from a livelihood } \\
\text { intervention? }\end{array}$ & & \\
\hline Christianity & 1042 & 88 & $\mathrm{No}$ & 970 & 82 \\
\hline Islam & 47 & 4 & Yes & 210 & 18 \\
\hline Traditional & 63 & 5 & Ethnicity & & \\
\hline Other & 28 & 2 & Fante & 626 & 53 \\
\hline Marital status & & & Nzema & 71 & 6 \\
\hline Married & 814 & 69 & $\mathrm{Ga}$ & 457 & 39 \\
\hline Never married & 217 & 18 & Ewe & 16 & 1 \\
\hline Divorced/Separated & 90 & 8 & Other & 10 & 1 \\
\hline Widowed & 59 & 5 & Community & & \\
\hline Wealth status & & & Elmina & 400 & 34 \\
\hline Poor & 543 & 46 & Jamestown & 388 & 33 \\
\hline Middle & 616 & 52 & Axim & 392 & 33 \\
\hline Rich & 21 & 2 & $\mathrm{~N}=1180$ & & \\
\hline \multicolumn{6}{|l|}{ Dependency ratio } \\
\hline Low & 338 & 29 & & & \\
\hline Moderate & 318 & 27 & & & \\
\hline High & 515 & 44 & & & \\
\hline
\end{tabular}




\subsection{Association between Livelihood Resilience and Independent Variables}

It is observed that (Table 2) most of the independent variables considered were associated with the livelihood resilience of respondents. Aside from the age of respondents and dependence on fishing as the only source of income, all other variables were associated $(p<0.05)$ with the resilience of their livelihoods. However, the strength of these associations varied across variables. Associations with moderate strengths (Cramér's between 0.2 and 0.6 ) were observed between livelihood resilience and respondent's membership of fisherfolk association/group, benefitting from a livelihood intervention, and community. The educational attainment, gender, religious affiliation, marital status, wealth status, dependency ratio, experience in fishing, and the ethnicity of the respondent had weak associations (Cramér's V less than 0.2) with livelihood resilience.

Table 2. Associations between livelihood resilience and predictor variables.

\begin{tabular}{|c|c|c|c|c|}
\hline \multirow{3}{*}{ Variable } & \multicolumn{3}{|c|}{ Livelihood Resilience } & \multirow{3}{*}{ Chi2 } \\
\hline & Less Resilient & Resilient & More Resilient & \\
\hline & $\%$ & $\%$ & $\%$ & \\
\hline \multicolumn{5}{|l|}{ Gender } \\
\hline Male & 37 & 19 & 44 & \multirow{3}{*}{$\begin{array}{l}\chi 2(2)=19.0928, p=0.000 \\
\quad \text { Cramér's V }=0.1272\end{array}$} \\
\hline Female & 47 & 22 & 31 & \\
\hline \multicolumn{4}{|c|}{ - enter } & \\
\hline Young-adults & 41 & 21 & 38 & \multirow{3}{*}{$\begin{array}{c}\chi 2(4)=7.9215, p=0.094 ; \text { Cramér's } \\
V=0.0579\end{array}$} \\
\hline Middle-aged adults & 38 & 19 & 43 & \\
\hline Old-aged adults & 46 & 23 & 31 & \\
\hline \multicolumn{5}{|l|}{ Educational attainment } \\
\hline No formal & 44 & 22 & 35 & \multirow{3}{*}{$\begin{array}{l}\chi 2(4)=12.0607, p=0.017 \\
\text { Cramér's V }=0.0715\end{array}$} \\
\hline Primary & 37 & 19 & 44 & \\
\hline Secondary/Post-secondary & 37 & 16 & 47 & \\
\hline \multicolumn{5}{|l|}{ Religious affiliation } \\
\hline Christian & 40 & 21 & 39 & \multirow{4}{*}{$\begin{array}{l}\chi 2(6)=17.5248, p=0.000 \\
\text { Cramér's V = } 0.0862\end{array}$} \\
\hline Muslim & 45 & 17 & 38 & \\
\hline Traditional & 30 & 10 & 60 & \\
\hline Other & 61 & 14 & 25 & \\
\hline \multicolumn{5}{|l|}{ Marital status } \\
\hline Married & 36 & 18 & 45 & \multirow{4}{*}{$\begin{array}{l}\chi 2(6)=31.2142, p=0.000 \\
\quad \text { Cramér's V }=0.1150\end{array}$} \\
\hline Never married & 45 & 24 & 31 & \\
\hline Divorced/Separated & 54 & 22 & 23 & \\
\hline Widowed & 51 & 22 & 27 & \\
\hline \multicolumn{5}{|l|}{ Wealth status } \\
\hline Poor & 49 & 17 & 34 & \multirow{3}{*}{$\begin{array}{l}\chi 2(4)=35.8217, p=0.000 \\
\text { Cramér's V }=0.1232\end{array}$} \\
\hline Middle & 33 & 22 & 45 & \\
\hline Rich & 19 & 19 & 62 & \\
\hline \multicolumn{5}{|l|}{ Dependency ratio } \\
\hline Low & 31 & 24 & 45 & \multirow{3}{*}{$\begin{array}{l}\chi 2(4)=16.9425, p=0.000 \\
\quad \text { Cramér's V }=0.0851\end{array}$} \\
\hline Moderate & 46 & 17 & 37 & \\
\hline High & 43 & 19 & 38 & \\
\hline \multicolumn{5}{|c|}{ Is fishing your only source of income? } \\
\hline No & 39 & 17 & 44 & \multirow{2}{*}{$\begin{array}{c}\chi 2(2)=1.6147, p=0.446 ; \text { Cramér's } \\
V=0.0370\end{array}$} \\
\hline Yes & 40 & 20 & 39 & \\
\hline \multicolumn{5}{|l|}{ Experience (years in fishing) } \\
\hline $1-15$ & 35 & 17 & 48 & \multirow{4}{*}{$\begin{array}{l}\chi 2(6)=26.4982, p=0.000 \\
\text { Cramér's V }=0.1060\end{array}$} \\
\hline $16-30$ & 44 & 20 & 36 & \\
\hline $31-45$ & 43 & 27 & 30 & \\
\hline $46-60$ & 31 & 31 & 38 & \\
\hline \multicolumn{5}{|c|}{ Membership of fisherfolk association/group? } \\
\hline No & 53 & 24 & 22 & \multirow{2}{*}{$\begin{array}{l}\chi 2(2)=242.4121, p=0.000 \\
\quad \text { Cramér's V }=0.4532\end{array}$} \\
\hline Yes & 19 & 13 & 68 & \\
\hline
\end{tabular}


Table 2. Cont.

\begin{tabular}{|c|c|c|c|c|}
\hline \multirow{3}{*}{ Variable } & \multicolumn{3}{|c|}{ Livelihood Resilience } & \multirow{3}{*}{ Chi2 } \\
\hline & Less Resilient & Resilient & More Resilient & \\
\hline & $\%$ & $\%$ & $\%$ & \\
\hline \multicolumn{5}{|c|}{ Previously benefitted from a livelihood intervention? } \\
\hline No & 46 & 22 & 32 & \multirow{2}{*}{$\begin{array}{l}\chi 2(2)=140.2586, p=0.000 \\
\quad \text { Cramér's V }=0.3448\end{array}$} \\
\hline Yes & 14 & 10 & 76 & \\
\hline \multicolumn{5}{|l|}{ Ethnicity } \\
\hline Fante & 40 & 13 & 48 & \multirow{5}{*}{$\begin{array}{c}\chi 2(8)=73.4865, p=0.000 \\
\text { Cramér's V }=0.1765\end{array}$} \\
\hline Nzema & 45 & 21 & 34 & \\
\hline $\mathrm{Ga}$ & 40 & 30 & 30 & \\
\hline Ewe & 25 & 0 & 75 & \\
\hline Other & 60 & 20 & 20 & \\
\hline \multicolumn{5}{|l|}{ Community } \\
\hline Elmina & 22 & 7 & 72 & \multirow{4}{*}{$\begin{array}{c}\chi 2(4)=305.5068, p=0.000 \\
\text { Cramér's V }=0.3598\end{array}$} \\
\hline Jamestown & 37 & 32 & 31 & \\
\hline Axim & 62 & 21 & 17 & \\
\hline $\mathrm{N}=1180$ & & & & \\
\hline
\end{tabular}

\subsection{Relationships between Livelihood Resilience and Independent Variables}

An ordered logistic regression was fitted to the data to determine the effect of the independent variables on the livelihood resilience of respondents. The results, as shown in Figure 5, indicate that sociocultural and contextual factors have significant effects on the livelihood resilience of respondents. Specifically, the respondent's religious affiliation, wealth status, dependency ratio, experience in fishing, membership of a fisherfolk association/group, previous benefits from livelihood interventions, ethnicity, and community had significant effects on their livelihood resilience. Respondents affiliated with the Islamic religion were less likely $(\mathrm{OR}=0.509 ; p=0.053)$ to have resilient livelihoods, as compared to those in the Christian faith (see also Table S1). Additionally, respondents who have not married $(\mathrm{OR}=0.441 ; p=0.000)$ and those who have divorced / separated $(\mathrm{OR}=0.585 ; p<0.05)$ were less likely to have resilient livelihoods, as compared to their married counterparts. In terms of wealth status, respondents with moderate-income were $46 \%$ more likely $(p<0.01)$, while respondents designated as rich were far more $(202 \%)$ likely $(p<0.05)$ to have resilient livelihoods, compared with those designated as poor. Respondents with moderate and high dependency ratios were, respectively, 49\% ( $p=0.000)$ and $53 \%(p=0.000)$ less likely to have resilient livelihoods, as compared to those with a low dependency ratio. With regard to experience in fishing, respondents into fishing/fish work for 16 to 30 years $(\mathrm{OR}=0.559 ; p=0.000)$ and 31 to 45 years $(\mathrm{OR}=0.583 ; p<0.05)$ were less likely to have resilient livelihoods, as compared to those into fishing/fish work for 1 to 15 years. Respondents who are members of fisherfolk association/groups were far more $(505 \%)$ likely $(p=0.000)$ to have a resilient livelihood, as compared to non-members. Similarly, respondents who have previously benefitted from a livelihood intervention were far more $(231 \%)$ likely $(p=0.000)$ to have resilient livelihoods, as compared to nonbeneficiaries. It is also observed that respondents who identify as Nzema ethnicity are $96 \%(p<0.05)$ more likely to have resilient livelihoods, as compared to the Fante group. Finally, respondents from Axim $(\mathrm{OR}=0.095 ; p=0.000)$ were less likely to have resilient livelihoods, as compared with those from Elmina. 


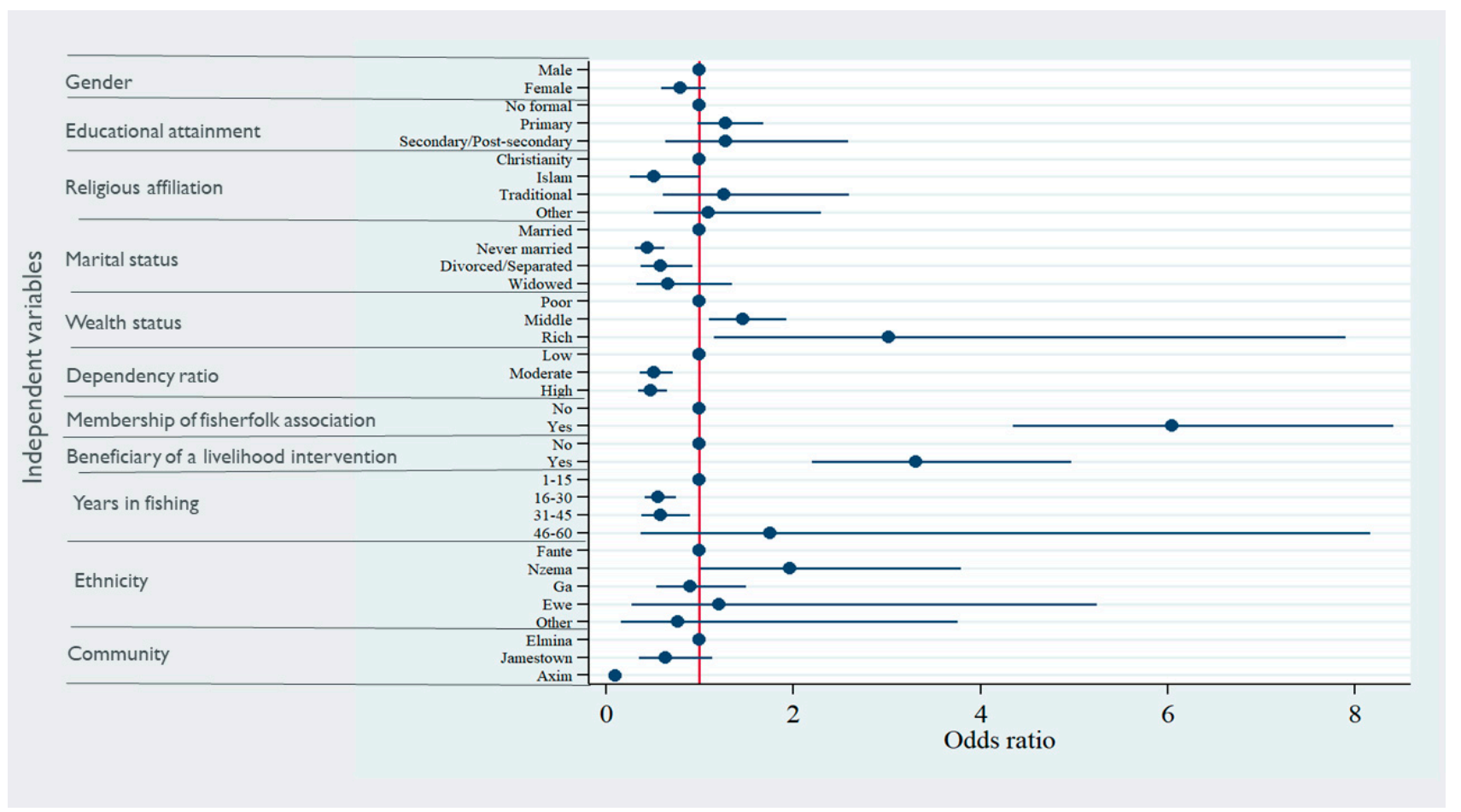

Figure 5. Effects of independent variables on the livelihood resilience of fisherfolk.

\section{Discussion}

This study contributes to the nascent body of literature on the measurement of livelihood resilience in small-scale fisheries. It empirically assessed the resilience of artisanal fisherfolk livelihoods to the declining fish catch in the small-scale fisheries of Ghana. The relationships between sociodemographic characteristics and other relevant factors and the resilience of fisherfolk's livelihood in Elmina, Jamestown, and Axim were investigated. It was found that the livelihoods of male fisherfolk in these communities were more resilient, as compared to females. This could be attributed to the often challenging household responsibilities that burden female- and male-dominant gender norms [69]. Despite this disparity in livelihood resilience between male and female fisherfolk, livelihood resilience was not associated with gender. This is particularly surprising, as studies indicate that fisherfolk activities contribute to buffer capacity (eg access to livelihood capitals), capacity for self-organization (norms and local rules), and learning, and management of the smallscale fisheries of Ghana are gendered $[45,69]$. This could be as a result of supplementary livelihood activities outside their notable gendered roles in the small-scale fisheries. For instance, Asare et al. (2019) found that small-scale fishers engage in oyster production as a supplementary income source in the face of the continuous decrease in fish catch [70]. Marschke and Berkes (2006) made similar observations, indicating that small-scale fishing households in Cambodia diversify their livelihood activities to cope with declines in the fishery. The young and middle-aged fisherfolk had more resilient livelihoods. Nevertheless, the age category of fisherfolk has no significant effect on the livelihood resilience of fisherfolk in the three communities. This is in contrast with previous studies that suggest that resilience in the livelihoods of artisanal fishers is linked to age, among other biosocial characteristics [21].

As opposed to Marshall and Marshall (2007), the educational attainment of fisherfolk did not affect their livelihood resilience against shocks from the declining fishery. However, the more resilient livelihoods found among fisherfolk with formal education (secondary/post-secondary, and primary level) could be attributed to the observed association between educational attainment and livelihood resilience. Education could increase access to livelihood capitals that determine fisherfolk buffer capacity—an important pillar 
of livelihood resilience. One of the potential pathways is the influence of education on fisherfolk's adoption of technology services that increase their off-fishing productivity in Ghana [71]. However, this link is invariably moderated by factors that determine access to these services such as ownership of mobile and access to internet service-a potential reason that education could have no significant effect on the livelihood resilience of fisherfolk.

In terms of religious affiliation, a majority of fisherfolk who identify as traditionalists had more resilient livelihoods. This could probably be due to the relatively limited congregational religious activities of the faith in Ghana, giving them more time to concentrate on livelihood activities. It was found that the livelihoods of fisherfolk affiliated with the Islamic faith were less likely to be resilient as compared to Christians. Many artisanal fishers in Ghana belong to the Christian faith [72,73]. It is expected that this broadens the social networks and potentials benefits from their membership of Christian unions. According to Lidzén (2008), in Ghana churches, similar to families, provide welfare services for their members [74]. Such support could limit barriers to the promotion of their livelihoods by enhancing access to livelihood capitals (buffer capacity), sharing knowledge, skills, and best practices (capacity for learning) on coping with threats to their livelihoods in times of challenges. The marital status of fisherfolk had a significant effect on the resilience of their livelihood. In Ghana's fishing communities, family members consisting of a husband and children commonly work as units and render support to each other [75]. It is, therefore, not surprising that fisherfolk who are not married and divorcees/separated are less likely to have resilient livelihoods, as compared to married folks. Partner support in various ways including tangible and intangible assets at the household level [69] could promote livelihood resilience building.

Another important finding is the significant effect of fisherfolk's wealth status on their livelihood resilience. Cinner et al. (2009) suggest that poverty excludes fisherfolk from adopting livelihood strategies that could potentially build resilience to shocks [76]. In Ghana's fishing communities, poverty is more prevalent among fisherfolk than others [13,77]. It is found that the likelihood of fisherfolk having a resilient livelihood increased with increasing wealth status. Wealth status, similar to buffer capacity, is largely determined by fisherfolk's access or ownership of critical assets. These assets could widen their capability to pursue livelihood adaptation strategies that increase resilience. Studies have found that low wealth status is commonly associated with a high dependency ratio [78]. An increase in dependency ratio was associated with less likelihood of having a resilient livelihood. Fisherfolk with large dependents (non-working) household members could bear huge responsibilities that limit their ability to make savings from their meagre incomes to cushion shocks. This could reduce their buffer capacity and, by extension, the resilience of their livelihood to the continuously declining fishery.

The experience of fisherfolk plays an important role in the resilience of the livelihoods of artisanal fishers [21]. This study found that fisherfolk's years of experience in fishing have a significant effect on the resilience of their livelihood. This is not surprising, as Owusu and Andriesse (2020) suggest that fisherfolk's level of experience in fishing is important in understanding their coping strategies/ responses to shocks including changes in fisheries management policy/regulation. It is, however, surprising that the likelihood of having a resilient livelihood decreased with increasing years of experience in fishing/fish work. Social learning [54], an important theoretical foundation of the capacity for learning in SESs, indicates that the process of learning involves constant observation and modelling through interactions with the social environment. It was, therefore, expected that likelihood of fisherfolk having a resilient livelihood would increase as the years they engage in fishing increased. Interestingly, membership of a fisherfolk association/group is associated with a greater likelihood of having a resilient livelihood. Fisherfolk social networks including associations, groups, and cooperatives in Ghana are noted for their contribution to the welfare of their membership [45,79]. Aside from serving as platforms for knowledge sharing among fisherfolk, the leadership of these social networks advances the interest 
of their membership in decision making. Such opportunities could lead to the resolution of their grievances, as well as increased political capital, thereby promoting livelihood resilience.

Over the years, the Government of Ghana (GoG), non-governmental organizations (local and international), and international development agencies such as the European Union (EU), the United States Agency for International Development (USAID), etc. have implemented various interventions to promote the livelihood of artisanal fishers [80-82]. It was, therefore, not surprising that fisherfolk who previously benefitted from livelihood intervention are more likely to have resilient livelihoods. The study found that ethnicity has an effect on the resilience of fisherfolk's livelihoods. This could potentially be due to the itinerant nature of fisherfolk in some ethnic groups [83,84]. Migration is one of the key livelihoods adaptative strategies fisherfolk employ [85-87]. It could either lead to access to better livelihood opportunities or assets than enhance livelihoods or hamper livelihood resilience building as a result of unsuitable vulnerability context. The Nzema people were more likely to have livelihoods being resilient, compared to the Fante group. This could be attributed to the proximity of the Nzema communities in western Ghana to the neighbouring Ivory Coast, facilitating migration [88].

Local context plays an important role in shaping livelihood resilience, as local institutions and responses (livelihood adaptation strategies) to shocks, among others, vary from place to place $[65,89,90]$. Conflicts between fisherfolk in the Western Region of Ghana, where Axim is located, and companies engaging in offshore oil exploration over ocean space have been reported over the years [91,92]. This had added a layer of vulnerability to the livelihoods of fisherfolk in communities along the western coast. This could account for less likelihood of the livelihoods of fisherfolk from Axim to be resilient, as compared to those from Elmina.

\section{Conclusions}

This paper sought to assess the livelihood resilience of artisanal fisherfolk to decreasing fish catch in three small-scale fishing communities (Elmina, Axim, and Jamestown) in Ghana. It was found that the resilience of fisherfolk livelihoods increased with increasing levels of educational attainment. There was also a significant gendered difference in livelihood resilience. Male fisherfolk with secondary/post-secondary level education had the highest proportion (50\%) of more resilient livelihood. Only 36\% of female fisherfolk with secondary/post-secondary level education had more resilient livelihoods. While $40 \%$ of male fisherfolk with no formal education had less resilient livelihoods, the livelihoods of half $(51 \%)$ of females fisherfolk with no formal education were less resilient. Livelihood resilience was associated with sociodemographic characteristics including age, gender, educational attainment, marital status, religion, wealth status, dependency ratio, ethnicity, community (contextual), and other relevant factors (experience in fishing, membership of fisherfolk association/group, and beneficiary of livelihood interventions). Aside from age and educational attainment, all other associated factors (religion, marital status, wealth status, dependency ratio, experience in fishing, ethnicity, membership of a fisherfolk association/group, and benefit from a livelihood intervention) had significant effects on the livelihood resilience of fisherfolk in the three communities. These findings suggest that interventions towards improving the livelihood resilience of fisherfolk need to consider individual-level characteristics, as well as contextual factors.

Supplementary Materials: The following are available online at https:/ / www.mdpi.com/article/10 .3390 / su131810404/s1, Table S1: Ordered logistic regression showing relationships between livelihood resilience and predictor variables.

Author Contributions: I.A. conceptualized and implemented the study. All aspects of the study were supervised by F.A.A. and D.W.A. All authors reviewed and approved for submission for publication. All authors have read and agreed to the published version of the manuscript. 
Funding: This research is part of an MPhil research funded by the World Bank Africa Center of Excellence in Coastal Resilience (ACECoR) Project (World Bank ACE Grant Number 6389-G) at the University of Cape Coast, Ghana.

Institutional Review Board Statement: Ethical clearance for this study given by the University of Cape Coast Institutional Review Board (UCCIRB)—Clearance Number UCCIRB/CANS/ 2020/06.

Informed Consent Statement: Following the guidelines issued by the UCCIRB, informed consent was obtained from all subjects involved in the study.

Data Availability Statement: The UCCIRB policies do not support the public sharing of the survey data.

Acknowledgments: The authors would like to thank the World Bank for funding this research. We also wish to express our sincere gratitude to Charles Atanga Adongo for supporting various aspects of the research. Finally, we acknowledge the hard work and contribution of the field assistants especially Emmanuel Darfour Marfo, George Raymond Eshun, and Iddrisu Salifu to this study.

Conflicts of Interest: The authors declare no conflict of interest.

\section{References}

1. Coulthard, S. Can We Be Both Resilient and Well, and What Choices Do People Have? Incorporating Agency into the Resilience Debate from a Fisheries Perspective. Ecol. Soc. 2012, 17, 4. [CrossRef]

2. Lam, V.; Cheung, W.; Swartz, W.; Sumaila, U. Climate change impacts on fisheries in West Africa: Implications for economic, food and nutritional security. Afr. J. Mar. Sci. 2012, 34, 103-117. [CrossRef]

3. Petrossian, G.A. Preventing illegal, unreported and unregulated (IUU) fishing: A situational approach. Biol. Conserv. 2015, 189, 39-48. [CrossRef]

4. Sumaila, U.R.; Ebrahim, N.; Schuhbauer, A.; Skerritt, D.; Li, Y.; Kim, H.S.; Mallory, T.G.; Lam, V.W.; Pauly, D. Updated estimates and analysis of global fisheries subsidies. Mar. Policy 2019, 109, 103695. [CrossRef]

5. Song, A.M.; Scholtens, J.; Barclay, K.; Bush, S.R.; Fabinyi, M.; Adhuri, D.S.; Haughton, M. Collateral damage? Small-scale fisheries in the global fight against IUU fishing. Fish Fish. 2020, 21, 831-843. [CrossRef]

6. Asiedu, B.; Okpei, P.; Nunoo, F.K.E.; Failler, P. A fishery in distress: An analysis of the small pelagic fishery of Ghana. Mar. Policy 2021, 129, 104500. [CrossRef]

7. Lima, M.; Canales, T.M.; Wiff, R.; Montero, J. The Interaction Between Stock Dynamics, Fishing and Climate Caused the Collapse of the Jack Mackerel Stock at Humboldt Current Ecosystem. Front. Mar. Sci. 2020, 7, 123. [CrossRef]

8. Penney, R.; Wilson, G.; Rodwell, L. Managing sino-ghanaian fishery relations: A political ecology approach. Mar. Policy 2017, 79, 46-53. [CrossRef]

9. Afoakwah, R.; Osei, M.B.D.; Effah, E. A Guide on Illegal Fishing Activities in Ghana. In USAID/Ghana Sustainable Fisheries Management Project; Coastal Resources Center, Graduate School of Oceanography, University of Rhode Island; Prepared by the University of Cape Coast: Narragansett, RI, USA, 2018; Ghana GH2014 \_SCI048\_UCC.

10. Akpalu, W.; Eggert, H. The economic, social and ecological performance of the industrial trawl fishery in Ghana: Application of the FPIs. Mar. Policy 2021, 125, 104241. [CrossRef]

11. Aheto, D.W.; Asare, N.K.; Quaynor, B.; Tenkorang, E.; Asare, C.; Okyere, I. Profitability of Small-Scale Fisheries in Elmina, Ghana. Sustainability 2012, 4, 2785-2794. [CrossRef]

12. EJF. Stolen at Sea. How illegal 'Saiko' Fishing is Fuelling the Collapse of Ghana's Fisheries. 2019. Available online: http: / / ejf.mudbank.uk/resources/downloads/Stolen-at-sea_06_2019.pdf (accessed on 7 July 2021).

13. Owusu, V.; Andriesse, E. From open access regime to closed fishing season: Lessons from small-scale coastal fisheries in the Western Region of Ghana. Mar. Policy 2020, 121, 104162. [CrossRef]

14. Development Action Association. Sensitization on Fisheries Management Plan with Fisher Folks and Fisheries Commission in Apam and Winneba. In USAID/Ghana Sustainable Fisheries Management Project (SFMP); Coastal Resources Center, Graduate School of Oceanography, University of Rhode Island and Development Action Association: Narragansett, RI, USA, 2017; GH2014 \_COM042 \_DAA.

15. Lazar, N.; Yankson, K.; Blay, J.; Ofori-Danson, P.; Markwei, P.; Agbogah, K. Status of the Small Pelagic Stocks in Ghana and Recommendations to Achieve Sustainable Fishing 2017. In Ghana Sustainable Fisheries Management Project; Coastal Resources Center, Graduate School of Oceanography, University of Rhode Island: Narragansett, RI, USA, 2018; GH2014 \_SCI042 \_CRC.

16. Ostrom, E. A General Framework for Analyzing Sustainability of Social-Ecological Systems. Science 2009, 325, 419-422. [CrossRef]

17. EJF. Call for Urgent Action to End Saiko to Save the Livelihoods of Over 2.7 million Ghanaians. 2020. Available online: https: / / ejfoundation.org/resources/downloads/Open-Letter-to-Ghanas-President.pdf (accessed on 7 July 2021).

18. Overå, R. Modernisation Narratives and Small-Scale Fisheries in Ghana and Zambia. Forum Dev. Stud. 2011, 38, 321-343. [CrossRef] 
19. Lawson, E.T.; Gordon, C.; Schluchter, W. The dynamics of poverty-environment linkages in the coastal zone of Ghana. Ocean. Coast. Manag. 2012, 67, 30-38. [CrossRef]

20. Olympio, G.; Amos-Abanyie, S. Effects of shoreline erosion on infrastructure development along the coastal belt of Ghana: Case of Nkontompo community. J. Sci. Technol. (Ghana) 2014, 33, 39. [CrossRef]

21. Satumanatpan, S.; Pollnac, R. Resilience of Small-Scale Fishers to Declining Fisheries in the Gulf of Thailand. Coast. Manag. 2019, 48, 1-22. [CrossRef]

22. Béné, C.; Arthur, R.; Norbury, H.; Allison, E.; Beveridge, M.; Bush, S.; Campling, L.; Leschen, W.; Little, D.; Squires, D.; et al. Contribution of Fisheries and Aquaculture to Food Security and Poverty Reduction: Assessing the Current Evidence. World Dev. 2016, 79, 177-196. [CrossRef]

23. Cinner, J.; Folke, C.; Daw, T.; Hicks, C. Responding to change: Using scenarios to understand how socioeconomic factors may influence amplifying or dampening exploitation feedbacks among Tanzanian fishers. Glob. Environ. Chang. 2011, $21,7-12$. [CrossRef]

24. Blythe, J.L. Resilience and social thresholds in small-scale fishing communities. Sustain. Sci. 2015, 10, 157-165. [CrossRef]

25. Coulthard, S. Adapting to environmental change in artisanal fisheries-Insights from a South Indian Lagoon. Glob. Environ. Chang. 2008, 18, 479-489. [CrossRef]

26. Freduah, G.; Fidelman, P.; Smith, T.F. Mobilising adaptive capacity to multiple stressors: Insights from small-scale coastal fisheries in the Western Region of Ghana. Geoforum 2018, 91, 61-72. [CrossRef]

27. Kalikoski, D.C.; Neto, P.Q.; Almudi, T. Building adaptive capacity to climate variability: The case of artisanal fisheries in the estuary of the Patos Lagoon, Brazil. Mar. Policy 2010, 34, 742-751. [CrossRef]

28. Walker, B.; Holling, C.S.; Carpenter, S.R.; Kinzig, A. Resilience, Adaptability and Transformability in Social-ecological Systems. Ecol. Soc. 2004, 9, 5. [CrossRef]

29. Adger, W.N.; Hughes, T.P.; Folke, C.; Carpenter, S.R.; Rockström, J. Social-ecological resilience to coastal disasters. Science 2005, 309, 1036-1039. [CrossRef] [PubMed]

30. Finkbeiner, E.; Micheli, F.; Saenz-Arroyo, A.; Vazquez-Vera, L.; Perafan, C.; Cardenas, J.-C. Local response to global uncertainty: Insights from experimental economics in small-scale fisheries. Glob. Environ. Chang. 2018, 48, 151-157. [CrossRef]

31. Tanner, T.; Lewis, D.; Wrathall, D.; Bronen, R.; Cradock-Henry, N.; Huq, S.; Lawless, C.; Nawrotzki, R.; Prasad, V.; Rahman, A.; et al. Livelihood resilience in the face of climate change. Nat. Clim. Chang. 2015, 5, 23-26. [CrossRef]

32. Speranza, C.I.; Wiesmann, U.; Rist, S. An indicator framework for assessing livelihood resilience in the context of social-ecological dynamics. Glob. Environ. Chang. 2014, 28, 109-119. [CrossRef]

33. Quandt, A.; Neufeldt, H.; McCabe, J.T. The role of agroforestry in building livelihood resilience to floods and drought in semiarid Kenya. Ecol. Soc. 2017, 22, 10. [CrossRef]

34. Sina, D.; Chang-Richards, A.Y.; Wilkinson, S.; Potangaroa, R. A conceptual framework for measuring livelihood resilience: Relocation experience from Aceh, Indonesia. World Dev. 2019, 117, 253-265. [CrossRef]

35. Liu, W.; Li, J.; Ren, L.; Xu, J.; Li, C.; Li, S. Exploring Livelihood Resilience and Its Impact on Livelihood Strategy in Rural China. Soc. Indic. Res. 2020, 150, 977-998. [CrossRef]

36. Zhou, W.; Guo, S.; Deng, X.; Xu, D. Livelihood resilience and strategies of rural residents of earthquake-threatened areas in Sichuan Province, China. Nat. Hazards 2021, 106, 255-275. [CrossRef]

37. Holling, C.S. Understanding the Complexity of Economic, Ecological, and Social Systems. Ecosystems 2001, 4, 390-405. [CrossRef]

38. Daniel, D.; Sutherland, M.; Speranza, C.I. The role of tenure documents for livelihood resilience in Trinidad and Tobago. Land Use Policy 2019, 87, 104008. [CrossRef]

39. Pandey, R.; Jha, S.K.; Alatalo, J.; Archie, K.M.; Gupta, A.K. Sustainable livelihood framework-based indicators for assessing climate change vulnerability and adaptation for Himalayan communities. Ecol. Indic. 2017, 79, 338-346. [CrossRef]

40. Freduah, G.; Fidelman, P.; Smith, T.F. Adaptive capacity of small-scale coastal fishers to climate and non-climate stressors in the Western region of Ghana. Geogr. J. 2019, 185, 96-110. [CrossRef]

41. Speranza, C.I. Resilience as a guiding principle for implementing practices and policies for climate variability and climate change in Africa. In Proceedings of the Global Science Conference on Climate-Smart Agriculture, Davis, CA, USA, $20-22$ March 2013.

42. Kuang, F.; Jin, J.; He, R.; Wan, X.; Ning, J. Influence of livelihood capital on adaptation strategies: Evidence from rural households in Wushen Banner, China. Land Use Policy 2019, 89, 104228. [CrossRef]

43. Bebbington, A. Capitals and Capabilities: A Framework for Analyzing Peasant Viability, Rural Livelihoods and Poverty. World Dev. 1999, 27, 2021-2044. [CrossRef]

44. Cumming, G.S. Conceptual Background on Social-Ecological Systems and Resilience. In Spatial Resilience in Social-Ecological Systems; Springer Science and Business Media LLC: Berlin/Heidelberg, Germany, 2011; pp. 7-33.

45. Torell, E.; Owusu, A.; Nyako, A.O. USAID/Ghana Sustainable Fisheries Management Project (SFMP), Ghana Fisheries Gender Analysis, 2015; Coastal Resources Center, Graduate School of Oceanography, University of Rhode Island: Narragansett, RI, USA, 2015; GEN002; 21p.

46. Lenselink, N.M. Participation in Artisanal Fisheries Management for Improved Livelihoods in West Africa: A Synthesis of Interviews and Cases from Mauritania, Senegal, Guinea and Ghana; Food \& Agriculture Organization: Rome, Italy, 2002.

47. Adjei, J.K.; Sika-Bright, S. Traditional beliefs and sea fishing in selected coastal communities in the Western Region of Ghana. Ghana J. Geogr. 2019, 11, 1-19. 
48. Olsson, P.; Schultz, L.; Folke, C.; Hahn, T. Social Networks for Ecosystem Management: A Case Study of Kristianstads Vattenrike, Sweden; Cent Interdiscip Environ Res (CTM); Stockholm University: Stockholm, Sweden, 2007.

49. Speranza, I.C. Resilient Adaptation to Climate Change in African Agriculture; Studies, Deutsches Institut für Entwicklungspolitik: Bonn, Germany, 2010.

50. Rockenbauch, T.; Sakdapolrak, P. Social networks and the resilience of rural communities in the Global South: A critical review and conceptual reflections. Ecol. Soc. 2017, 22. [CrossRef]

51. Grafton, R.Q. Social capital and fisheries governance. Ocean. Coast. Manag. 2005, 48, 753-766. [CrossRef]

52. Argyris, C.; Schön, D. Organizational Learning; Addison \& Wesley: Reading, MA, USA, 1978.

53. De Kraker, J. Social learning for resilience in social-Ecological systems. Curr. Opin. Environ. Sustain. 2017, 28, 100-107. [CrossRef]

54. Bandura, A. Social-learning theory of identificatory processes. In Handbook of Socialization Theory and Research; Rand McNally \& Company: Chicago, IL, USA, 1969; Volume 213, p. 262.

55. Tam, J.; Waring, T.; Gelcich, S.; Chan, K.M.A.; Satterfield, T. Measuring behavioral social learning in a conservation context: Chilean fishing communities. Conserv. Sci. Pr. 2021, 3, e336. [CrossRef]

56. Benhangi, S.M.; Bagheri, A.; Abolhassani, L.; Razi, H.H. Assessing the learning capacity of water users-Adoption a social learning framework. J. Hydrol. 2020, 590, 125496. [CrossRef]

57. Jerez-Gómez, P.; Cespedes-Lorente, J.; Valle, R. Organizational learning capability: A proposal of measurement. J. Bus. Res. 2005, 58, 715-725. [CrossRef]

58. Rist, S.; Chidambaranathan, M.; Escobar, C.; Wiesmann, U.; Zimmermann, A. Moving from sustainable management to sustainable governance of natural resources: The role of social learning processes in rural India, Bolivia and Mali. J. Rural. Stud. 2007, 23, 23-37. [CrossRef]

59. Li, X.; Kunnathur, A.S.; Ragu-Nathan, T.S.; Jitpaiboon, T. Development and Validation of Learning Capability Construct in IOS Supply Chain Network Context. In Decision Sciences Institute 2008 Annual Meeting Baltimore. Available online: https://www. yumpu.com/en/document/view/35516992/development-and-validation-of-learning-capability-construct-in-ios- (accessed on 6 July 2021).

60. Bain, L.E.; Zweekhorst, M.B.M.; Amoakoh-Coleman, M.; Muftugil-Yalcin, S.; Omolade, A.-O.; Becquet, R. To keep or not to keep? Decision making in adolescent pregnancies in Jamestown, Ghana. PLoS ONE 2019, 14, e0221789.

61. Bain, L.E.; Muftugil-Yalcin, S.; Amoakoh-Coleman, M.; Zweekhorst, M.B.M.; Becquet, R.; Buning, T.D.C. Decision-making preferences and risk factors regarding early adolescent pregnancy in Ghana: Stakeholders' and adolescents' perspectives from a vignette-based qualitative study. Reprod. Health 2020, 17, 141. [CrossRef] [PubMed]

62. Ghana Statistical Service. 2010 Population \& Housing Census: District Analytical Report, Nzema East Municipality. 2014. Available online: https://www2.statsghana.gov.gh/docfiles/2010_District_Report/Western/NZEMAEAST.pdf (accessed on 8 July 2021).

63. Amissah, A.A. Demographic characteristics and willingness to remain single: The case of male single-parents in Elmina, Ghana. Norma 2021, 16, 57-72. [CrossRef]

64. Armah, F.A.; Ekumah, B.; Yawson, D.O.; Odoi, J.O.; Afitiri, A.-R.; Nyieku, F.E. Access to improved water and sanitation in sub-Saharan Africa in a quarter century. Heliyon 2018, 4, e00931. [CrossRef] [PubMed]

65. Marschke, M.; Berkes, F. Exploring Strategies that Build Livelihood Resilience: A Case from Cambodia. Ecol. Soc. 2006, 11, 1-6. [CrossRef]

66. Marshall, N.; Marshall, P.A. Conceptualizing and Operationalizing Social Resilience within Commercial Fisheries in Northern Australia. Ecol. Soc. 2007, 12, 1-5. [CrossRef]

67. Jones, L.; Tanner, T. Measuring 'subjective resilience': Using peoples' perceptions to quantify household resilience. Overseas Dev. Inst. Work. Pap. 2015, 423, 1-15. [CrossRef]

68. Nguyen, K.V.; James, H. Measuring household resilience to floods: A case study in the Vietnamese Mekong River Delta. Ecol. Soc. 2013, 18, 3. [CrossRef]

69. Torell, E.; Bilecki, D.; Owusu, A.; Crawford, B.; Beran, K.; Kent, K. Assessing the Impacts of Gender Integration in Ghana's Fisheries Sector. Coast. Manag. 2019, 47, 507-526. [CrossRef]

70. Asare, B.; Obodai, E.; Acheampong, E. Mangrove oyster farming: Prospects as supplementary livelihood for a Ghanaian fishing community. J. Fish. Coast. Manag. 2019, 1, 7. [CrossRef]

71. Twumasi, M.A.; Jiang, Y.; Zhou, X.; Addai, B.; Darfor, K.N.; Akaba, S.; Fosu, P. Increasing Ghanaian fish farms' productivity: Does the use of the internet matter? Mar. Policy 2021, 125, 104385. [CrossRef]

72. Amevenku, F.K.Y.; Asravor, R.K.; Kuwornu, J.K.M. Determinants of livelihood strategies of fishing households in the volta Basin, Ghana. Cogent Econ. Financ. 2019, 7, 1-15. [CrossRef]

73. Setsoafia, E.D.; Owusu, P.; Danso-Abbeam, G. Estimating Profit Efficiency of Artisanal Fishing in the Pru District of the BrongAhafo Region, Ghana. Adv. Agric. 2017, 2017, 1-7. [CrossRef]

74. Lidzén, L. A Comparative Study of the Social Welfare Provided by Three Christian Churches in Accra, Ghana. Available online: https:/ / www.diva-portal.org/smash/get/diva2:120028/FULLTEXT01.pdf (accessed on 8 July 2021).

75. Adusah-Karikari, A. Black gold in Ghana: Changing livelihoods for women in communities affected by oil production. Extr. Ind. Soc. 2015, 2, 24-32. [CrossRef] 
76. Cinner, J.; Daw, T.; McClanahan, T. Socioeconomic Factors that Affect Artisanal Fishers' Readiness to Exit a Declining Fishery. Conserv. Biol. 2009, 23, 124-130. [CrossRef]

77. Bluwey, F.A. Poverty among Fisher-Folk and Crop-Based Farmer Households in the Komenda Edina Eguafo Abrem District in the Central Region Ghana; University of Cape Coast: Cape Coast, Ghana, 2012.

78. Baulch, B.; McCulloch, N. Being Poor and Becoming Poor: Poverty Status and Poverty Transitions in Rural Pakistan. J. Asian Afr. Stud. 2002, 37, 168-185. [CrossRef]

79. Abane, H.; Akonor, E.; Ekumah, E.; Adjei, J. Four Governance Case Studies and their Implications for Ghana Fisheries Sector. In USAID-URI Integrated Coastal and Fisheries Governance Initiative; Coastal Resources Center, Graduate School of Oceanography, University of Rhode Island: Narragansett, RI, USA, 2013; p. 80.

80. Edna Ekua Kwansima Quansa. Scoping Assessment of Sustainable Livelihood Opportunities in the Artisanal Fishing Communities of the Central Region of Ghana. Available online: https:/ / ejfoundation.org/resources/downloads/Sustainable_livelihood_ opportunities_fishing_Ghana.pdf (accessed on 7 July 2021).

81. Asiedu, B.; Nunoo, F.K.E. An Investigation of Fish Catch Data and Its Implications for Management of Small-scale Fisheries of Ghana. Int. J. Fish. Aquat. Sci. 2013, 2, 46-57. Available online: http://www.academia.edu/download/44429124 /An_Investigation_of_Fish_Catch_Data_and_20160405-30694-1517uan.pdf\%0Ahttp:/ / s3.amazonaws.com/academia.edu. documents /44429124/An_Investigation_of_Fish_Catch_Data_and_20160405-30694-1517uan.pdf?AWSAccessKeyId=AKIAIW (accessed on 8 July 2021).

82. Kwarteng, E.; Nsiah, A.; Samey, B.; Boateng, L.; Aziebor, E. Livelihood Options Synthesis Report. In The USAID/Ghana Sustainable Fisheries Management Project (SFMP); Coastal Resources Center, Graduate School of Oceanography, University of Rhode Island: Narragansett, RI, USA, 2016; GH2014 \_ACT072\_SNV.

83. Atuobi, R. Resource Management and the Challenges of Migration in Artisanal Fisheries. A Case Study on the Mobility of the Fishing People in Jamestown and Chorkor Fishing Communities in Ghana. Master's Thesis, UiT The Arctic University of Norway, Tromso, Norway, 2016.

84. Osei, I.; Yankson, K.; Obodai, E. Demographic and profitability analyses of the West African mangrove oyster (Crassostrea tulipa) fishery in the Densu delta, Ghana. J. Fish. Coast. Manag. 2020, 2, 12-22. [CrossRef]

85. Kraan, M. Creating Space for Fishermen's Livelihoods: Anlo-Ewe Beach Seine Fishermen's Negotiations for Livelihood Space within Multiple Governance Structures in Ghana; Leiden: African Studies Centre: Leiden, Netherlands, 2009.

86. Owusu, V. Impacts of the petroleum industry on the livelihoods of fisherfolk in Ghana: A case study of the Western Region. Extr. Ind. Soc. 2019, 6, 1256-1264. [CrossRef]

87. Yang, J.; Owusu, V.; Andriesse, E.; Ablo, A.D. In-Situ Adaptation and Coastal Vulnerabilities in Ghana and Tanzania. J. Environ. Dev. 2019, 28, 282-308. [CrossRef]

88. Valsecchi, P. The 'True Nzema': A Layered Identity. Africa 2001, 71, 391-425. [CrossRef]

89. Quandt, A. Measuring livelihood resilience: The Household Livelihood Resilience Approach (HLRA). World Dev. 2018, 107, 253-263. [CrossRef]

90. Sarker, N.I.; Wu, M.; Alam, G.M.; Shouse, R.C. Livelihood resilience of riverine island dwellers in the face of natural disasters: Empirical evidence from Bangladesh. Land Use Policy 2020, 95, 104599. [CrossRef]

91. Adjei, M. Governing the Ocean Space for the Coexistence of Fishery and Petroleum Industry in Ghana's Western Region; The University of Bergen: Bergen, Norwa, 2017.

92. Ovadia, J.S.; Ayelazuno, J.A.; Van Alstine, J. Ghana's petroleum industry: Expectations, frustrations and anger in coastal communities. J. Mod. Afr. Stud. 2020, 58, 397-424. [CrossRef] 